\title{
Appendiceal Carcinoid pTO TNM Finding v7
}

National Cancer Institute

\section{Source}

National Cancer Institute. Appendiceal Carcinoid pT O TNM Finding v7. NCI Thesaurus.

Code C89924.

Appendiceal carcinoid with no evidence of primary tumor. (from AJCC 7th Ed.) 